\title{
The consequences of the inappropriate use of ventilation systems operating in indoor swimming pool conditions - analysis
}

\author{
Izabela Pietkun-Greber ${ }^{1}$, Dariusz Suszanowicz ${ }^{1, *}$ \\ ${ }^{1}$ University of Opole, Department of Process Engineering, 7-9 Dmowskiego St., 45-365 Opole, \\ Poland
}

\begin{abstract}
Increasingly more leisure facilities, such as water parks or indoor swimming pools are being built in Poland nowadays. In order to ensure the air quality required by standards for such leisure facilities it is necessary to fit them with effectively functioning ventilation. For the removal of excess humidity, as well as chlorine ions occurring as a result of the disinfection of water as well as the carbon dioxide emitted by people using the facility, the ventilation system needs to be appropriately designed and efficient. For this reason, studies into the air quality in such facilities were undertaken. The paper presents the causes and consequences of the inappropriate operation and maintenance of ventilation systems in swimming pools. The study found that the causes of deterioration in the technical condition of the system which was operated in an environment with chlorine ions were: an inappropriate manufacture of its components and the wrong choice of construction materials for the given environment of operation. Furthermore, failure to follow the manufacturer's guidelines for the operation and maintenance of the components of the ventilation system greatly precipitated its degradation and the occurrence of sick building syndrome in the swimming pool. Solutions were found and proposed in order to improve the efficiency of the ventilation system in the given swimming-pool facility.
\end{abstract}

\section{Introduction}

The high relative humidity of air and air pollution in indoor swimming pools mainly result from the water evaporation from swimming pool basins and substances used for its disinfection [1]. Mold, bacteria and fungi growing in such humid conditions may have a significant impact on the health of people staying for a long time in the area. This phenomenon may also cause discomfort for people working in these types of recreational facilities and have a significant impact on the degradation of materials used inside swimming pool buildings [2]. To ensure the required air quality standards, it is necessary to use the ventilation system of an indoor swimming pool building [3]. For these facilities, at least three exchanges of the entire volume of indoor air within an hour should be provided.

\footnotetext{
*Corresponding author: d.suszanowicz@uni.opole.pl
} 
Ventilation systems for indoor swimming pools should operate continuously throughout the year. The water temperature in most basins is maintained between $27^{\circ} \mathrm{C}$ and $30^{\circ} \mathrm{C}$, the air temperature is between 1 and $2^{\circ} \mathrm{C}$ higher than the water temperature. This is important for the comfort of bathing and for reducing the rate of water evaporation from the basin. Indoor swimming pools therefore require much more energy for heating and ventilation than any other public buildings. For the above-mentioned reasons, a very important challenge is to guarantee the required air quality while ensuring the maximum energy efficiency of the devices used.

While in use, the air handling unit filters, exchanges, heats and dehumidifies air in the swimming pool hall. Due to the use of recirculated air, the entire internal surface as well as structural elements and individual components of the control panel are subject to constant contact with aggressive air. For this reason, the pool ventilation unit and its internal equipment needs to be properly secured and made of high quality materials resistant to corrosion [4]. An important factor affecting the correct operation of the device is also appropriate service and the timeliness of technical inspections.

The complexity and variety of solutions, as well as various requirements for installations, have led designers and users to care for the devices' reliability and durability. The greatest threat to the installation is corrosion (galvanic, pitting). The invention of stainless steel and stainless alloys was thought to be a solution to that problem. It turned out, however, that corrosion attacks all metals and even plastics. Among the factors causing corrosion centers we can distinguish [5]:

- materials used: chemical composition, properties,

- design and execution: assembly, metal arrangement, geometry,

- preparatory activities: cleaning, etching, rinsing, leak and insulation testing,

- medium: physicochemical properties, microorganisms,

- operating conditions: temperature, operating and flow conditions,

- other factors: the use of inadequate assembly tools made of carbon steel, a lack of cleaning of deposits and dust off the control panel elements' surface.

In order to analyze the effectiveness of removing excess moisture and pollutants contained in the air in the building of the indoor swimming pool, and to assess the energy efficiency and reliability of the ventilation system, an indoor swimming pool with a 25-meter pool has been chosen as the research facility.

\section{Materials and methods}

The research object in which the analyses were carried out were two air handling units located in the building of an indoor swimming pool, commissioned in 2011. Both air handling units were equipped with cross-flow heat exchangers, heat pumps for heat recovery from the air removed from the swimming pool hall and water heaters for the final heat treatment of the supply air. For the air handling unit No. 1, the heat pump was selected based on the assumed recirculation at the amount of $9850 \mathrm{~m}^{3} / \mathrm{h}(70 \%$ of the nominal flowthe amount of outside air $4250 \mathrm{~m}^{3} / \mathrm{h}$ ). The air temperature after mixing $+10.5^{\circ} \mathrm{C}$, at an outdoor temperature of $-20^{\circ} \mathrm{C}$. The drying capacity for the above-mentioned mode $\mathrm{W}_{\text {nom }}=$ $136 \mathrm{~kg} / \mathrm{h}$; the drying performance during summer $\mathrm{W}_{\text {summer }}=44 \mathrm{~kg} / \mathrm{h}$; the maximum drying efficiency $\mathrm{W}_{\max }=251 \mathrm{~kg} / \mathrm{h}$. For the air handling unit No. 2, the selection of the heat pump installed in the central office was based on the assumed recirculation at the amount of $8,550 \mathrm{~m}^{3} / \mathrm{h}\left(70 \%\right.$ of the nominal flow - the amount of external air $\left.3650 \mathrm{~m}^{3} / \mathrm{h}\right)$. The air temperature after mixing $+9.8^{\circ} \mathrm{C}$, at an outdoor temperature of $-20^{\circ} \mathrm{C}$. The drying capacity for the above-mentioned mode $\mathrm{W}_{\text {nom }}=122 \mathrm{~kg} / \mathrm{h}$; the drying performance during summer $\mathrm{W}_{\text {summer }}=40 \mathrm{~kg} / \mathrm{h}$; maximum drying efficiency $\mathrm{W}_{\max }=217 \mathrm{~kg} / \mathrm{h}$. Other technical parameters are summarized in Table 1. 
Table 1. Technical parameters of the central units.

\begin{tabular}{|c|c|c|c|c|}
\hline \multirow{2}{*}{ Parameter } & \multicolumn{2}{|c|}{ Air handling unit 1} & \multicolumn{2}{|c|}{ Air handling unit 2} \\
\hline & Intake & Exhaust & Intake & Exhaust \\
\hline Prefilter & F5 & F5 & F5 & F5 \\
\hline \multirow{2}{*}{$\begin{array}{l}\text { Type of heat exchanger } \\
\text { Temperature in front of the exchanger } \\
{\left[{ }^{\circ} \mathrm{C}\right]}\end{array}$} & \multicolumn{2}{|c|}{ cross-flow } & \multicolumn{2}{|c|}{ cross-flow } \\
\hline & 10.5 & 30 & 9.8 & 30 \\
\hline Humidity in front of the exchanger [\%] & 100 & 60 & 100 & 60 \\
\hline Temperature behind the exchanger $\left[{ }^{\circ} \mathrm{C}\right]$ & 22.5 & 20.5 & 22.2 & 20.3 \\
\hline Humidity behind the exchanger [\%] & 47 & 100 & 45 & 100 \\
\hline Efficiency [\%] & 60 & 50 & 61 & 49 \\
\hline \multirow[t]{2}{*}{ Heat pump exchanger } & condenser & evaporator & condenser & evaporator \\
\hline & \multicolumn{2}{|c|}{ Drying mode } & & \\
\hline Condenser power [kW] & 39.5 & 47 & 39 & 47 \\
\hline $\begin{array}{l}\text { Temperature in front of the exchanger } \\
{\left[{ }^{\circ} \mathrm{C}\right]}\end{array}$ & 32 & 30 & 32 & 30 \\
\hline Humidity in front of the exchanger [\%] & 45 & - & 45 & - \\
\hline Temperature behind the exchanger $\left[{ }^{\circ} \mathrm{C}\right.$ & 23.9 & 40 & 22.7 & 41 \\
\hline Humidity behind the exchanger [\%] & 72 & - & 77 & - \\
\hline & Heating moc & & & \\
\hline Condenser power $[\mathrm{kW}]$ & 46.5 & 38.5 & 45 & 38.1 \\
\hline $\begin{array}{l}\text { Temperature in front of the exchanger } \\
{\left[{ }^{\circ} \mathrm{C}\right]}\end{array}$ & 22.2 & 20.5 & 22,2 & 20.3 \\
\hline Humidity in front of the exchanger [\%] & o] & 100 & - & 100 \\
\hline Temperature behind the exchanger $\left[{ }^{\circ} \mathrm{C}\right.$ & 31.7 & 18 & 33 & 17.4 \\
\hline Humidity behind the exchanger [\%] & - & 100 & - & 100 \\
\hline & Heater & & & \\
\hline Type of heater & water & - & water & - \\
\hline Heater power $[\mathrm{kW}]$ & 25 & - & 16.5 & - \\
\hline Temperature in front of the heater $\left[{ }^{\circ} \mathrm{C}\right]$ & 31.7 & - & 33 & - \\
\hline Temperature behind the heater $\left[{ }^{\circ} \mathrm{C}\right]$ & 37 & - & 37 & - \\
\hline & Fan & & & \\
\hline Type of ventilator & Radial-axial with & direct drive & Radial-axial w & direct drive \\
\hline Airflow $\left[\mathrm{m}^{3} / \mathrm{h}\right]$ & \begin{tabular}{l|l}
14100 & \\
\end{tabular} & 14100 & 12200 & 12100 \\
\hline External static pressure $[\mathrm{Pa}]$ & 600 & 600 & 600 & 600 \\
\hline Rated motor power $[\mathrm{kW}]$ & 7.5 & 7.5 & 5.5 & 5.5 \\
\hline & Compresso & & & \\
\hline & Dehumidifying & node & & \\
\hline Cooling power $[\mathrm{kW}]$ & - & $2 \times 19.8$ & - & $2 \times 19.55$ \\
\hline Input power $[\mathrm{kW}]$ & - & $2 \times 3.71$ & - & $2 \times 3.82$ \\
\hline $\mathrm{COP} / \mathrm{COP}_{\mathrm{g}}$ & \begin{tabular}{l|l}
- & \\
\end{tabular} & 5.33 & - & 5.12 \\
\hline & Heating moc & & & \\
\hline Cooling power $[\mathrm{kW}]$ & 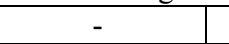 & $2 \times 19.8$ & - & $2 \times 19.55$ \\
\hline Input power $[\mathrm{kW}]$ & - & $2 \times 3.12$ & - & $2 \times 3.05$ \\
\hline $\mathrm{COP} / \mathrm{COPg}$ & - & 7.35 & - & 7.39 \\
\hline
\end{tabular}

The parts of the air handling units are made of the following materials:

- external sheathing - aluzinc coated sheet,

- internal lining (walls, upper cover plate) - aluzinc coated sheet,

- inner side of the floor panels - X5CrNi18-10 stainless steel sheet (1.4301),

- leachate basin - X5CrNi18-10 stainless steel sheet (1.4301),

- guides - X5CrNi18-10 stainless steel,

- frame, damper blades - aluminum. 
The energy efficiency of the ventilation system and heating of the air entering the indoor swimming pool hall have also been analyzed [6].

\section{Results}

The studies assessed the state of the air handling units. A visual inspection of available internal and external structural elements of both ventilation units showed significant corrosion damage, which negatively affects both the quality of air entering the pool hall and the life cycle of the installation itself [7]. Heavy surface damage and material losses were observed at the bottom of the cover panels made of aluzinc-coated metal sheet. White (corrosion of zinc) and red corrosion products were present on the surface of the cover panels-degradation of the coating (Fig. 1-2).
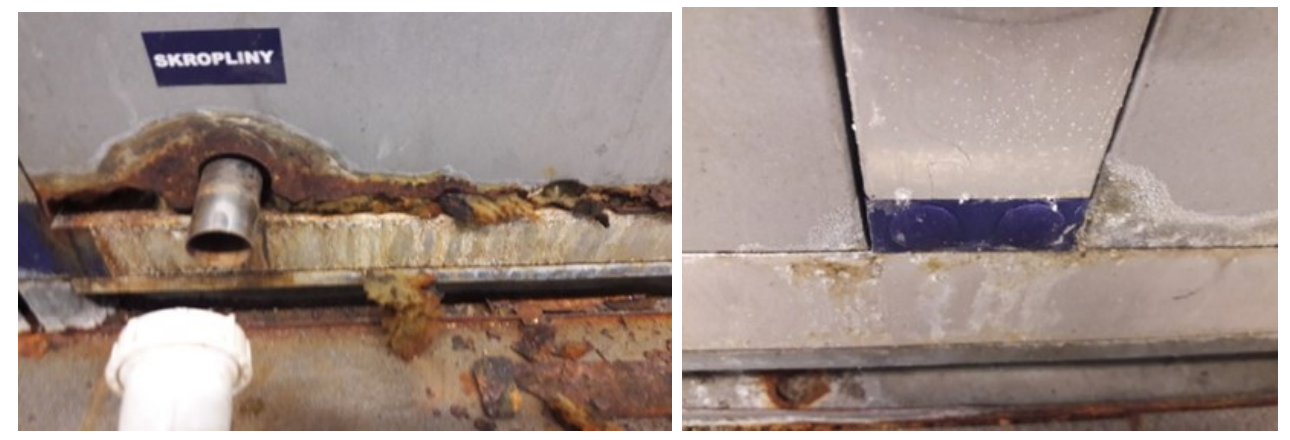

Fig. 1. View of the external cover panels of the air handling unit (air handling unit 1).

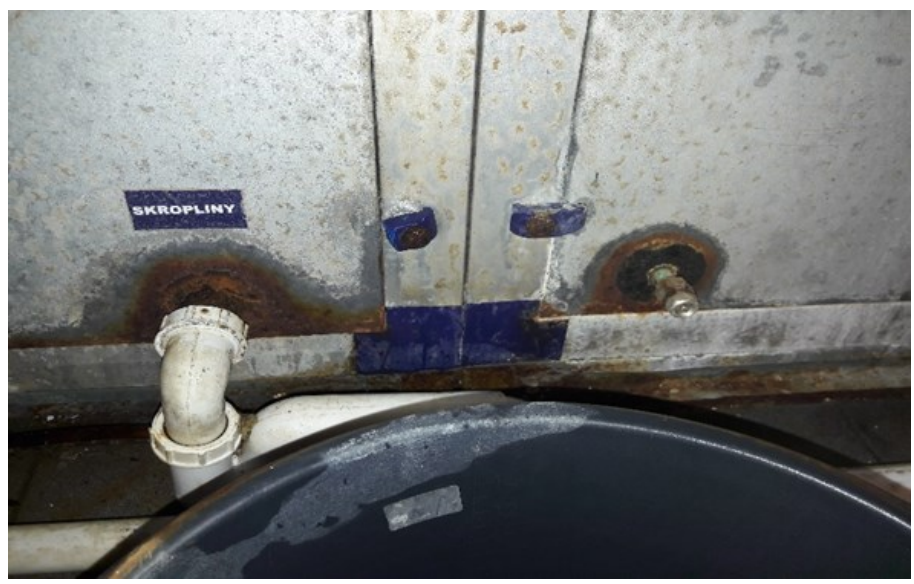

Fig. 2. View of the external cover panels of the air handling unit (air handling unit 2).

Corrosive damage and products of the corrosive process taking place were also observed on the side panels of the unit (Fig. 3) and floor panels made of X5CrNi18-10 sheets (corrosion pits) in various sections of the units (Fig. 4). Damper blades (Fig. 5), droplet separator (Fig. 6) and aluminum guides (Fig. 7) were also subject to corrosion. 

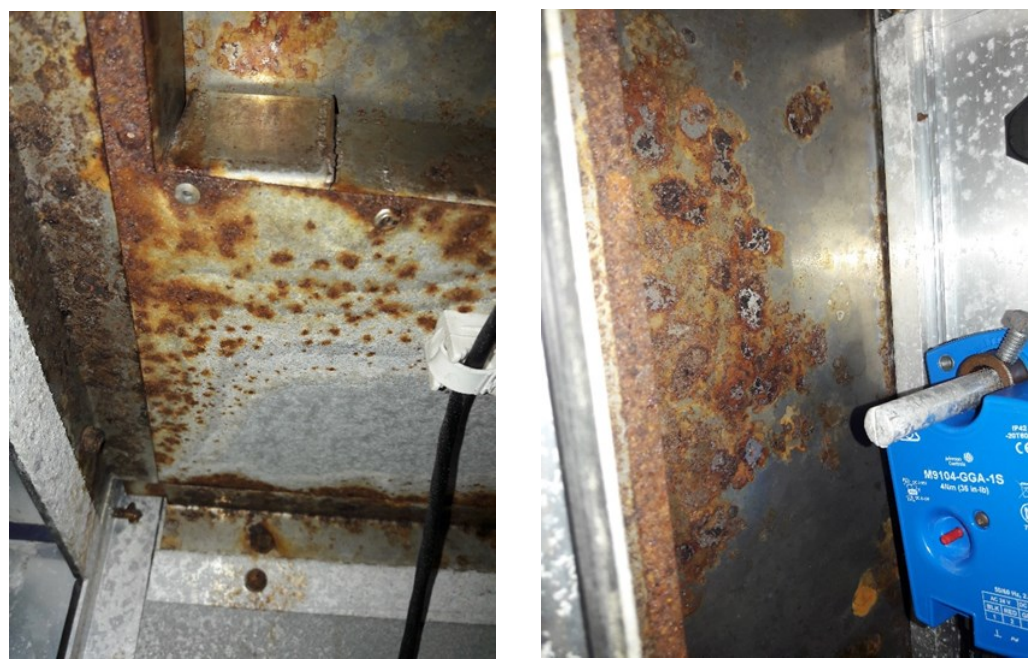

Fig. 3. View of the inner surface of the unit's side panels.
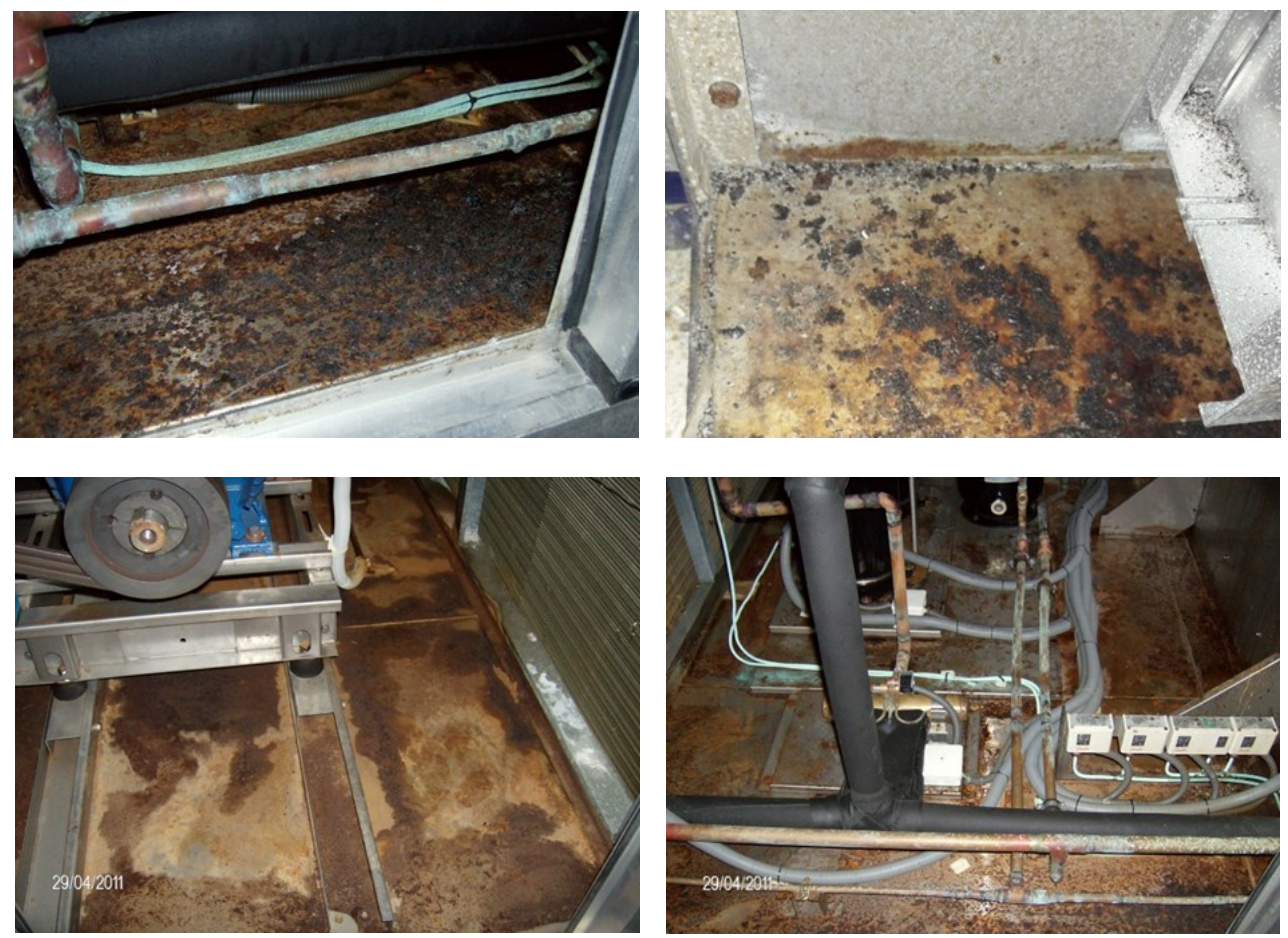

Fig. 4. View of the inner surface of the unit's floor panels. 


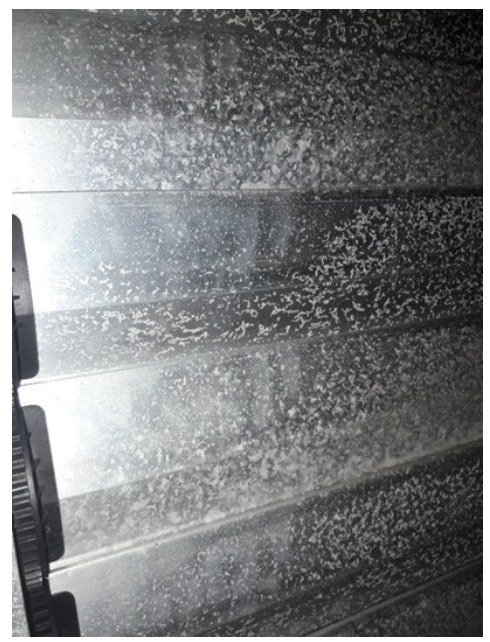

Fig. 5. View of the damper blades' surfaces made of aluminum in unit 1.
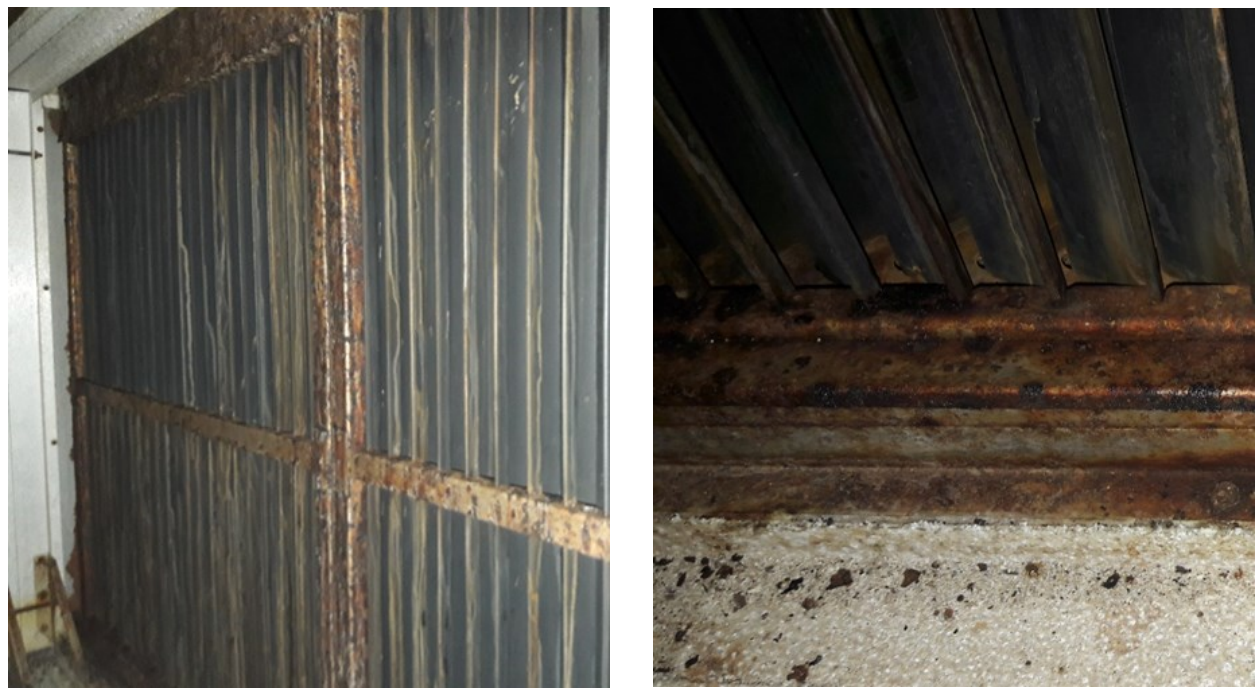

Fig. 6. View of the evaporator area in unit 1.

The analysis of the available documentation showed that in the initial stage of operation of the ventilation unit, the construction of the wall air intake did not ensure adequate protection of the unit against the influence of weather conditions. The lack of a protective roof has caused an additional amount of water coming from atmospheric precipitation (rain, snow) to enter the intake duct. The water excess (rainfall and moisture from the air removed from the pool hall) was not sufficiently discharged from the condensate tray of the ventilation unit, which resulted in overflow outside the tray. The lack of the possibility to drain the excess water contributed to premature damage to the floor panel surface.

In order to prevent damage to the air handling units, several modernizations of the solutions applied in both units were suggested.

The appropriate use of construction materials, corrosion protection and appropriate instructions and recommendations regarding maintenance are essential for the life cycle of pool system parts in a swimming pool environment [8]. 
A necessary condition for a rational choice of material meeting the requirements set at the design stage is a careful analysis of steel grades, taking technical and economic optimization criteria into account. Virtually none of the available steel is completely resistant to corrosion in the microclimate of swimming pools. In environments containing water vapor, the use stainless steels of an austenitic structure is recommended. In swimming pool buildings, for parts that are not both structural elements and are not subjected to continuous washing by the basin water steel $316(316 \mathrm{Ti}, 316 \mathrm{~L}, 316 \mathrm{LM})$ or higher corrosion resistance steel (when there is a risk of SCC corrosion cracking) are used. More corrosion-resistant types of steel than those commonly used in swimming pools are, for example, 904L (austenitic), ferritic-austenitic steel also called duplex steel (1.4462) or super duplex (1.4507) [9]. Duplex steel, compared to that commonly used, is characterized by high strength properties, good ductility and much higher corrosion resistance, especially in environments containing chlorine ions.

Appropriate anti-corrosion protection of the parts of swimming pool installations operating in conditions of high humidity and an aggressive medium is a key factor allowing an increase in their life cycle and failure-free operation. The increased corrosion resistance of parts can be achieved by: painting with wet epoxy paints or powder surface protection with chemicals-cataphoresis process, the application of polymer coatings in the form of polyester, polyamide or epoxy resins (electrostatic or fluidizing).

At the same time, installing a ground-coupled heat exchanger outside of the building was suggested, through which fresh air drawn in by the field intake from the building's surroundings would be introduced into the ventilation system. An example of a groundcoupled heat exchanger is shown in Fig. 7.

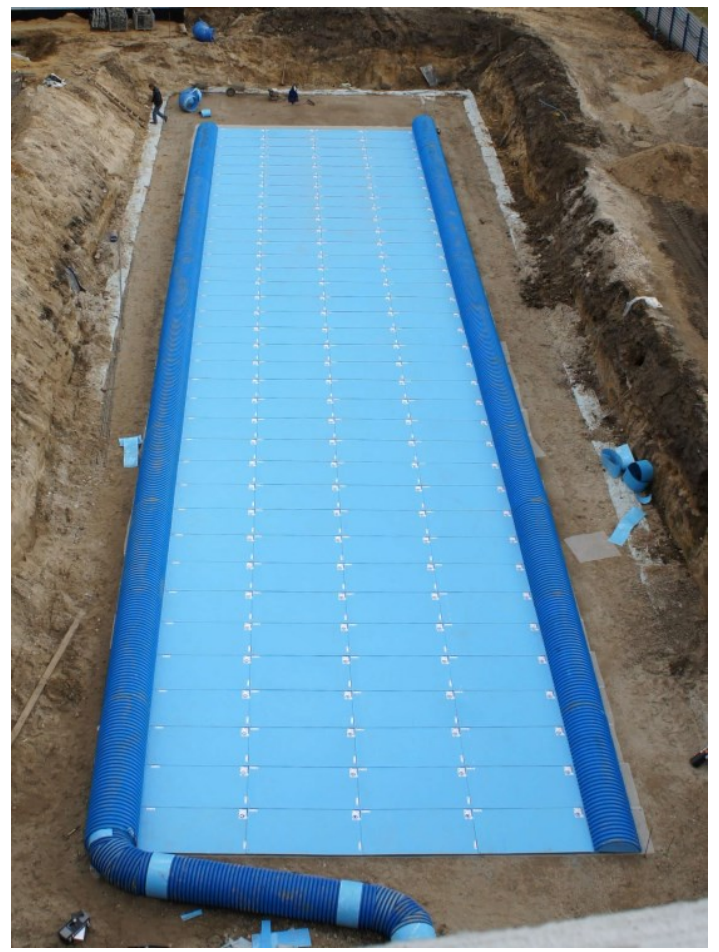

Fig. 7. Suggested solution of a ground-coupled heat exchanger [10]. 
Use of a ground-coupled heat exchanger of $120 \mathrm{~m}^{2}$ will allow reducing the energy needed to heat the air entering the pool hall by $11 \%$ on average over the year (from $2 \%$ during summer to $23 \%$ in the coldest winter months).

\section{Summary}

- One of the key factors for the failure-free operation of swimming pool air handling units is the appropriate selection of materials for the construction of their components and adequate anti-corrosion protection of devices operating in conditions of very high humidity.

- The factor influencing the energy-efficient operation of a ventilation system is also their correct operation and the timeliness of technical inspections.

- At the design stage, an alternative material solution should be considered, in particular the use of high-alloy ferritic-austenitic steel resistant to the chlorine environment, or the use of unalloyed steel coated with conventional paint coatings.

- Install a ground-coupled heat exchanger outside the building has been suggested, through which air will be introduced into air handling units. This will allow reducing the energy needed to heat the air entering the pool hall by $11 \%$ on average during the year.

\section{References}

1. F. Asdrubali, Energ. Buildings, 41, (2009)

2. A. Bernard, S. Carbonnelle, C. de Burbure, O. Michel, M. Nickmilder, Environ. Health Persp., 114(10), (2006)

3. PN-EN 15251:2012, Parametry wejściowe środowiska wewnętrznego dotyczące projektowania i oceny charakterystyki energetycznej budynków, obejmujące jakość powietrza wewnętrznego, środowisko cieplne, oświetlenie i akustykę (Indoor environmental input parameters for design and assessment of energy performance of buildings addressing indoor air quality, thermal environment, lighting and acoustics).

4. PN-EN 10088-1 Stale odporne na korozję. Część 1: Gatunki stali odpornych na korozję (Stainless steels - Part 1: List of stainless steels).

5. http://www.rynekinstalacyjny.pl (access: 12 January 2018)

6. E. Ribeiro, H. Jorge, D. Quintela, Int. J. Sustain. Energ., 35(4), (2016)

7. T.L. Bird, Build. Serv. Eng. Res. T., 9(1), (1988)

8. W. Ozgowicz, E. Kalinowska-Ozgowicz, S. Lesz, A. Kowalski, Rynek instalacyjny, 10, (2013)

9. J. Fischer, A. Burket, L. Mietz, Corros. Eng. Sci. Techn., 46(1), (2011)

10. http://ventus.info.pl (access: 10 November 2017)

11. P. Sedek, J. Brózda, J. Gazdowicz, Eng. Fail. Anal., 15(4), (2008) 